\title{
PENGARUH AIR REBUSAN AKAR ARU (Caesalpinia bonduc) TERHADAP KUALITAS SPERMA EPIDIDIMIS MENCIT (Mus musculus) : DASAR PENGEMBANGAN OBAT KONTRASEPSI TRADISIONAL BAGI LAKI-LAKI
}

\author{
D. Setiadi* dan S. Bachri* \\ (Laboratorium Biologi FKIP Unram)
}

\begin{abstract}
Abstrak
Indonesia memiliki banyak tumbuhan berpotensi obat salah satunya bisa dijadikan sebagai obat kontrasepsi tradisonal yang biasa digunakan untuk menjarangkan anak atau sterilisasi seperti rebusan akar Caesalpinia bonduc (Aru). Tujuan penelitian untuk mengetahui pengaruh obat kontrasepsi tradisional air rebusan akar aru terhadap kualitas pematangan sperma epididimis mencit (Mus musculus). Mencit dipilih secara acak untuk mewakili 4 kelompok dosis yaitu : 0,0 (K0), 16,0 (K1) 24,0 (K2) dan 32,0 (K3) l/gram berat badan/hari. Setiap kelompok perlakuan dilakukan dengan 5 kali replikasi. Perlakuan diberikan melalui oral dengan menggunakan jarum gavage selama 10 hari berturut-turut. Pembedahan dilakukan pada hari pertama setelah perlakuan selesai. Pengamatan kualitas sperma epididimis dengan perhitungan produksi sperma, \% sperm motil, \% sperma hidup, \% sperma abnormal,dan rangking keaktifan sperma. Untuk mengetahui ada atau tidaknya perbedaan yang bermakna antar perlakuan dalam kelompok dilakukan uji Anava satu arah, bila terdapat perbedaan bermakna dilanjutkan uji BNJ untuk membandingkan angka rata-rata antar kelompok perlakuan. Pemberian air rebusan akar Caesalpinea bonduc pada mencit menunjukan pengaruh perbedaan secara signifikan pada jumlah (\%) sperma abnormal antara dosis 0,0 l dengan 24,0 dan 32,0 l serta antara 16,0 l dengan 24,0 dan 32,0 l; Jumlah (\%) sperma hidup terdapat perbedaan antara dosis 0,0 l dengan 16,0, 24,0 dan 32,0 l; Jumlah (\%) sperma motil terdapat perbedaan antara dosis 0,0 l dengan 24,0 dan 32,0 l; Rangking keaktifan sperma terdapat perbedaan antara dosis 0,0 l dengan 24,0 dan 32,0 l. Pemberian rebusan akar aru berpengaruh secara signifikan terhadap peningkatan persen sperma abnormal, dan penuruan persen sperma hidup, motil dan keaktifan.
\end{abstract}

\begin{abstract}
Indonesia has many species of plants that have potent of medicine, one of them cold be as an traditional contraception medicine ussually used to limit child or sterilizatiom such as root boiled water of Caesalpinia bonduc. The aims of this study is to know the effect of root boiled water of Caesalpinia bonduc as traditional contraception medicine on quality of sperm maturation of epididymis of mice (Mus musculus). Mice were choosed radomly and doses gouped: 0,0 (KO), 16,0 (K1) 24,0 (K2) and 32,0 (K3) l/gram body weight/day. Each of group was replicated 5 times. Treatment were given by oral with using gavage needle for ten days. Surgery was carried out on first day after completing treatments. Examination of epidymis sperm by counting number of sperm production, percentage of motil, live, abnormal sperm, and rank of sperm motility. In order to know the deferences between control and treated group, was used one way anava analysis and analysed value for comparing between teratment group. The treatments of root boiled water of Caesalpinia bonduc have effect significantly on percentage of abnormal sperm between dose of 0,0 $l$ with 24,0 and 32,0 l, also between 16,0 l with 24,0 and 32,0 l. Percentage of live sperem is different between dose of 0,0 $l$ with 16,0, 24,0 and 32,0 l. Percentage of motile sperm is defferent significantly between dose of 0,0 $l$ with 24,0 and 32,0 l. Meanwhile percentage of motile rank has difference between dose of 0,0 $l$ with 24,0 and 32,0 $\quad l$. The treatment of root boiled water of Caesalpinia bonduc has effect signifiantly on increasing percentange of sperm abnormality, decreasing percentage of life sperm, motile and rank of motile of mice sperm.
\end{abstract}




\section{Pendahuluan}

$\mathrm{I}$ ndonesia termasuk negara dengan pertumbuhan penduduk yang relatif tinggi, sehingga masalah kependudukan merupakan masalah yang cukup mendapat perhatian dari pemerintah. Banyak usaha yang telah dilakukan pemerintah dalam usaha untuk menurunkan laju pertumbuhan penduduk diantaranya dengan program Keluarga Berencana (KB). Dalam dua puluh lima terakhir keberhasilan KB sudah semakin tampak dengan menurunnya pertumbuhan penduduk per tahun. Namun demikian hal tersebut tetap perlu dikendalikan agar pertumbuhan penduduk sesuai dengan dukung yang tersedia dan tidak melebihi apa yang sudah ditargetkan oleh pemerintah.

Program KB berfokus pada pengendalian kelahiran dan peningkatan kualitas kehidupan keluarga melalui kesehatan lingkungan, makanan Ibu dan Anak. Dalam usaha pengendalian kelahiran bermacam macam alat/obat kontrasepsi telah digunakan oleh laki-laki atau perempuan. Tetapi kebanyakan alat kontrasepsi ditujukan terutama untuk kaum wanita seperti IUD, PIL, Susuk, sedangkan bagi pria terbatas hanya pada penggunaan kondom dan sterilisasi (vasektomi).

Dalam beberapa tahun terakhir penelitian dibidang kontrasepsi khusus untuk laki-laki difokuskan untuk mempengaruhi proses perkembangan sperma (Spermatogenesis) terutama targetnya adalah miosis germ sel bebas efek samping (Glasier, 2000) dan proses pematangan sperma (Spermiogenesis) pada bagian epididimis, dengan tujuan akhir agar sperma tidak mampu membuahi sel telur. Penggunaan obat kontasepsi sintetik dihadapkan dengan efek samping yang relatif tinggi dan harga yang semakin mahal sehingga sangat sulit dijangkau oleh masyarakat pedesaan. Alternatif lain adalah penggunaan produk alam sebagai obat alternatif yang rendah efek samping dan harganya. Selain itu sebagian besar masyarakat saat ini telah menunjukan kecenderungan yang kuat untuk menempuh gaya hidup kembali ke alam dalam mencapai tujuan hidup yang lebih sehat dan aman dari berbagai macam gangguan kesehatan.

Banyak tumbuhan berpotensi bahan kontraseptif di banyak daerah yang dijadikan sebagai obat kontrasepsi tardisonal. Salah satu diantaranya yang biasa digunakan untuk menjarangkan anak atau sterilisasi oleh perempuan di pedalaman kabupaten Sumbawa yaitu rebusan akar Caesalpinia bonduc. Dari hasil penelitian terdahulu menunjukan rebusan akar aru menyebabkan terjadi kerusakan pada sel folikel primer dan sekunder $(43 \%)$ pada ovarium dan kerusakan pada sel hati namun tidak tampak kerusakan pada sel ginjal (Setiadi dan Merta, 2000). Selain itu ekstrak buah ranti bisa menurunkan laju fertilitas (Haryadi dan Wijanyanti, 1996), ekstrak buah tekokak menurunkan laju implantasi (Adil, 1997), ekstrak daun manggis menurunkan produksi sperma pada testis dan jumlah pada epididimis (Riono, et al. 1998). serta sambiloto telah banyak diteliti dan mempunyai khasiat menurunkan kadar progesteron, mempengaruhi spermatogenesis (Dalimartha, 2002) dan menurunkan glukosa (Syarieta, 2002). Diduga yang dipengaruhi oleh rebusan akar aru pada mencit betina adalah sistim hormonal terutama yang berhubungan dengan hormon yang diperlukan untuk perkembangan sel telur/folikel seperti LH dan FSH. Oleh karena itu perlu dilakukan penelitian pengaruh air rebusan akar aru (Caesalpinia Bonduc) terhadap kualitas pematangan sperma epididimis mencit (Mus musculus)

\section{Bahan dan Metode \\ Pemeliharaan Mencit}

Hewan yang digunakan adalah mencit betina galur BALB_C berumur 8 minggu dengan berat badan berkisar 24-30 gram. Mencit dipelihara dalam kandang terbuat dari fiber glass. Kandang dialasi sekam yang diganti setiap 3 hari. Makanan berupa pakan 
babi (cp551) dan minuman air dari PDAM diberikan secara berlebihan. Setiap kandang diletakan di atas rak dan diberi penerangan 12 jam per hari serta sirkulasi udara baik. Setiap 2 hari botol air minum dicuci bersih dengan deterjen dan setiap minggu ruangan disemprot dengan alkohol $70 \%$.

\section{Pembuatan Rebusan Akar Caesalpinia bonduc (Aru)}

Sebanyak 1000 gram akar Caesalpinia bonduc (Aru) direbus dalam $300 \mathrm{ml}$ air, sampai mencapai volume $100 \mathrm{ml}$. Kemudian air rebusan tersebut disimpan dalam lemari es untuk siap digunakan.

\section{Perlakuan}

Seminggu sebelum perlakuan semua hewan percobaan diaklimatisasikan dalam ruangan pemeliharaan dan setiap hewan ditimbang untuk menentukan dosis yang akan diberikan. Mencit dipilih secara acak untuk mewakili 4 kelompok dosis yaitu : 0,0 (K0), 16,0 (K1) 24,0 (K2) dan 32,0 (K3)

$1 / \mathrm{gr}$ berat badan/hari. Setiap kelompok perlakuan dilakukan dengan 5 kali replikasi. Perlakuan diberikan selama 10 hari berturutturut melalui oral dengan menggunakan jarum gavage. Pembedahan dilakukan pada hari pertama setelah perlakuan selesai.

\section{Pengamatan Uji Kualitas Sperma Epididimis}

Perhitungan produksi sperma

Jumlah produksi sperma epididimis dalam $1 \mathrm{ml}$ sampel (dari tiap kelompok perlakuan) dihitung dengan cara sampel dihisap dengan pipet thoma leukositometer sampai batas 0,5 kemudian diencer 20 kali dengan menambahkan larutan $\mathrm{Na} \mathrm{Cl} 0,85 \%$. Pipet dikocok agar larutan homogen dan dengan membuang 5 tetes pertama selanjutnya sampel diteteskan ke dalam kamar hitung improved Neubouner. Jumlah sperma dalam 2X16 kotak besar dari satu diagonal dihitung dengan counter di bawah mikroskop dengan pembesaran 400X, kemudian dihitung konsentrasi per ml cairan sampel dari epididimis.

Perhitungan \% sperm motil

Persentase sperma motil dihitung dengan cara sampel (dari tiap perlakuan) dihisap dengan pipet thoma leukositometer samapi batas 0,5 kemudian diencer 20 kali dengan menambahkan larutan $\mathrm{Na} \mathrm{Cl}$ 0,85\%. Pipet dikocok agar larutan homogen dan dengan membuang 5 tetes pertama selanjunya sampel diteteskan ke dalam kamart hitung improved Neubouner. Jumlah sperma motil dan tidak bergerak dalam 2X16 kotak besar dari satu diagonal dihitung dengan counter di bawah mikroskop dengan pembesaran 400X. Jumlah persen sperma motil dihitung dengan cara: jumlah sperma motil dibagi total sperma dikali 100

\section{Perhitungan \% sperma hidup}

Setetes sampel (dari tiap perlakuan) dan larutan eosin y $0,5 \%$ dicampur dengan homogen dalam gelas arloji. Setetes dari campuran tersebut diletakan dalam gelas objek dan segera ditutup dengan gelas penutup. Sperma mati akan tampak merah. Persentase sperma hidup dihitung dengan cara : jumlah sperma tidak tampak merah di bagi total sperma yang tampak dalam lapang pandang dikali 100.

\section{Perhitungan \% Sperma abnormal}

Setetes sampel (dari tiap perlakuan) diletakan pada gelas obyek, kemudian dengan bantuan gelas obyek dibuat preparat gosok. Setelah kering difiksasi dengan methanol 93\% selama 4 menit, kemudian diwarnai dengan larutan giemsa selama 30 menit dan dicuci dengan air mengalir. Persentase sperma tidak normal dihitung dengan cara: jumlah sperma tidak normal 
dibagi total sperma yang tampak dalam lapang pandang dikali 100.

Penentuan rangking keaktifan sperma

Sampel sperma epididimis dalam $1 \mathrm{ml}$ dari tiap perlakuan dihisap dengan pipet thoma leukositometer sampai batas 0,5 kemudian diencer 20 kali dengan menambahkan larutan $\mathrm{Na} \mathrm{Cl} \quad 0,85 \%$. Penentuan rangking keaktifan sperma dilakukan dengan diteteskan sampel pada objek gelas kenudian dilihat doi bawah mikroskop dan kemudian dirangking 0-5 dengan keterangan sebagai berikut $: 0=$ tidak bergerak, 1 = sedikit bergerak ke arah ekor tapi tidak pindah tempat, $2=$ sedikit berpindah tempat, biasanya berputar, $3=$ bergerak, umumnya berbentuk kurva, $4=$ bergerak cepat dengan arah lurus, dan $5=$ bergerak sangat cepat dengan arah yang lurus (Rodger, et al., 1991).

\section{Analisa Data}

Untuk mengetahui ada atau tidaknya perbedaan yang bermakna antar perlakuan dalam kelompok dilakukan uji Anava satu arah, bila terdapat perbedaan bermakna dilanjutkan uji BNJ untuk membandingkan angka rata-rata antar kelompok perlakuan (Sujana, 1992).

\section{Hasil dan Pembahasan}

\section{Persentase Sperma Abnormal}

Pemberian air rebusan akar aru Caesalpinea bonduc pada mencit menunjukan pengaruh signifikan terhadap jumlah (\%) sperma abnormal mencit, hal tersebut ditunjukan dengan hasil uji statistik dimana F hit> F tab (18,7 : 3,24). Tampak kecenderungan meningkat dari jumlah sperma abnormal dengan meningkatnya dosis yang diberikan, pada dosis 0,0 1 sebanyak rata-rata $32,73 \%$ sedangkan pada dosis 32,0

1 sebanyak $56,56 \%$ (gambar 1) sperma abnormal. Hasil uji BNJ menunjukan bahwa terdapat perbedaan jumlah (\%) sperma abnormal antara kelompok dosis $0,0 \quad 1$ dengan 24,0 dan 32,0 1 serta antara $16,0 \quad 1$ dengan 24,0 dan 32,0 .

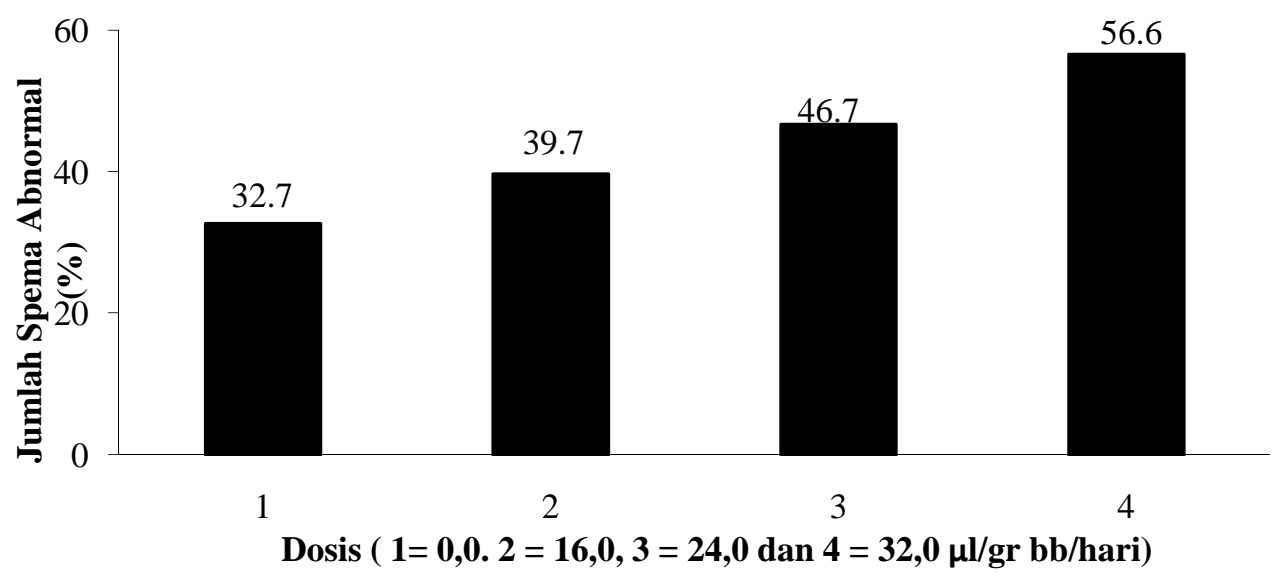

Gambar 1 Pengaruh Rebusan Air Akar Aru (Caesalpinea bonduc) Terhadap Jumlah (\%) Sperma Epididimis Abnormal Mencit (Mus musculus) 


\section{Persentase sperma hidup}

Pemberian air rebusan akar aru Caesalpinea bonduc pada mencit menunjukan pengaruh secara signifikan terhadap jumlah (\%) sperma hidup, ditunjukan dengan hasil uji statistik dimana $\mathrm{F}$ hit> $\mathrm{F}$ tab $(4,84:$ 3,24). Tampak kecenderungan menurun dari jumlah (\%) seperma hidup dengan meningkatnya dosis yang diberikan, pada dosis 0,01 sebanyak $61,7 \%$ sedangkan pada dosis $32,0 \quad 1$ sebanyak 38,34\% sperma hidup (gambar 2). Hasil uji BNJ menunjukan bahwa terdapat perbedaan antara kelompok dosis $0,0 \quad 1$ dengan 16,0, 24,0 dan 32,0 1 .

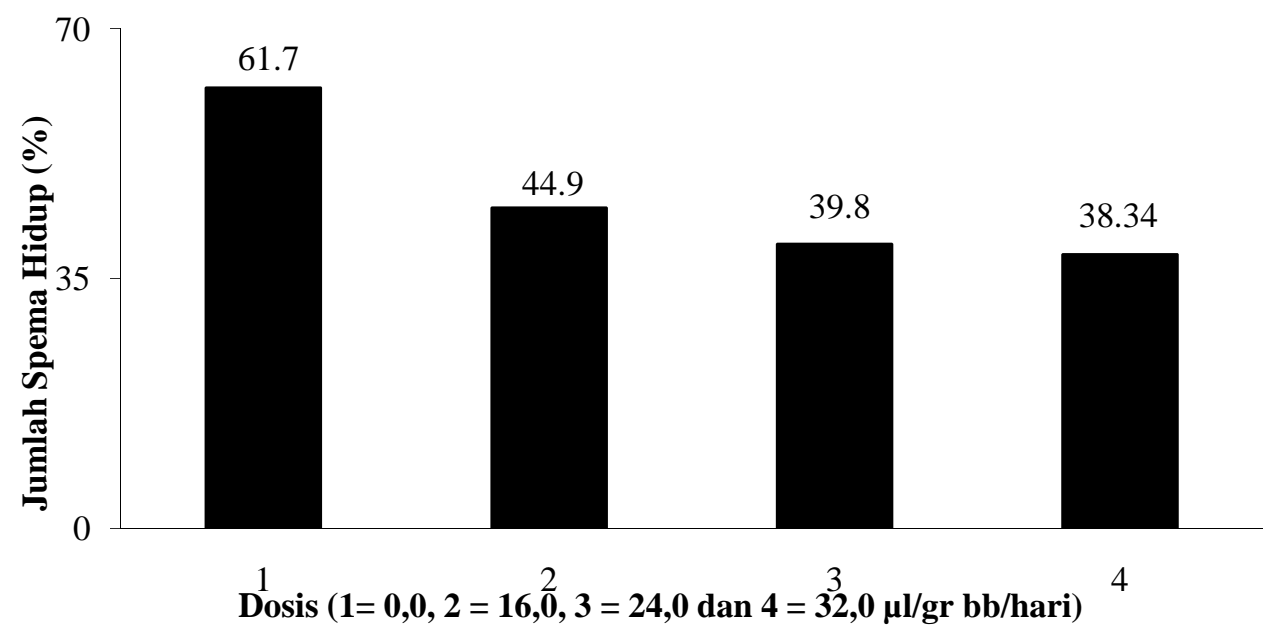

Gambar 2 Pengaruh Rebusan Air Akar Aru (Caesalpinea bonduc) Terhadap Jumlah (\%) Sperma Hidup Mencit (Mus musculus)

\section{Persentase Sperma Motil}

Pemberian air rebusan akar aru Caesalpinea bonduc pada mencit menunjukan pengaruh secara signifikan terhadap jumlah (\%) sperma motil, ditunjukan dengan hasil uji statistik dimana $\mathrm{F}$ hit> F tab (5,64: 3,24). Tampak kecenderungan menurun dari jumlah (\%) seperma motil dengan meningkatnya dosis yang diberikan, pada dosis $0,0 \quad 1$ sebanyak $57,7 \%$ sedangkan pada dosis $32,0 \quad 1$ sebanyak 40,82\% sperma motil (gambar 3). Hasil uji BNJ menunjukan bahwa terdapat perbedaan antara kelompok dosis $0,0 \quad 1$ $\begin{array}{llll}\text { dengan } & 24,0 \quad \text { dan } & 32,0 & 1 .\end{array}$ 


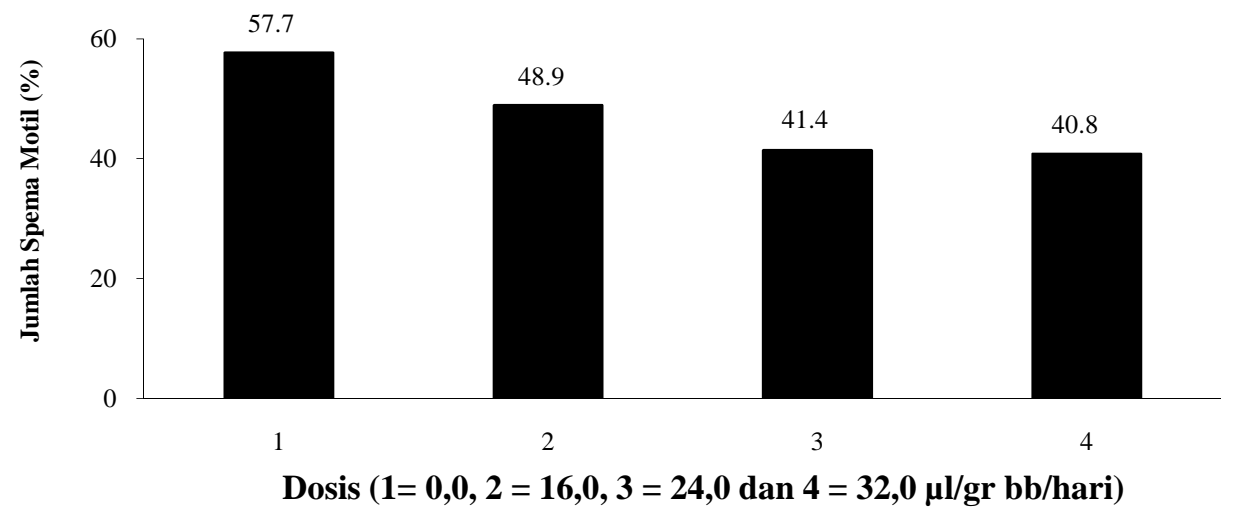

Gambar 3 Pengaruh Rebusan Air Akar Aru (Caesalpinea bonduc) Terhadap Jumlah (\%) Sperma Motil Mencit (Mus musculus)

\section{Rangking Keaktifan Sperma}

Pemberian air rebusan akar aru Caesalpinea bonduc pada mencit menunjukan pengaruh secara signifikan terhadap rangking keaktifan sperma, ditunjukan dengan hasil uji statistik dimana $\mathrm{F}$ hit> $\mathrm{F}$ tab $(5,62: 3,24)$. Tampak kecenderungan menurun dari rengking keaktifan dengan meningkatnya dosis yang diberikan, pada dosis $0,0 \quad 1$ setinggi 3,8 sedangkan pada dosis 32,0 1 setinggi 2,8 (gambar4). Hasil uji BNJ menunjukan bahwa terdapat perbedaan dalam keaktifan sperma antara kelompok dosis 0,0 1 dengan 24,0 dan 32,0

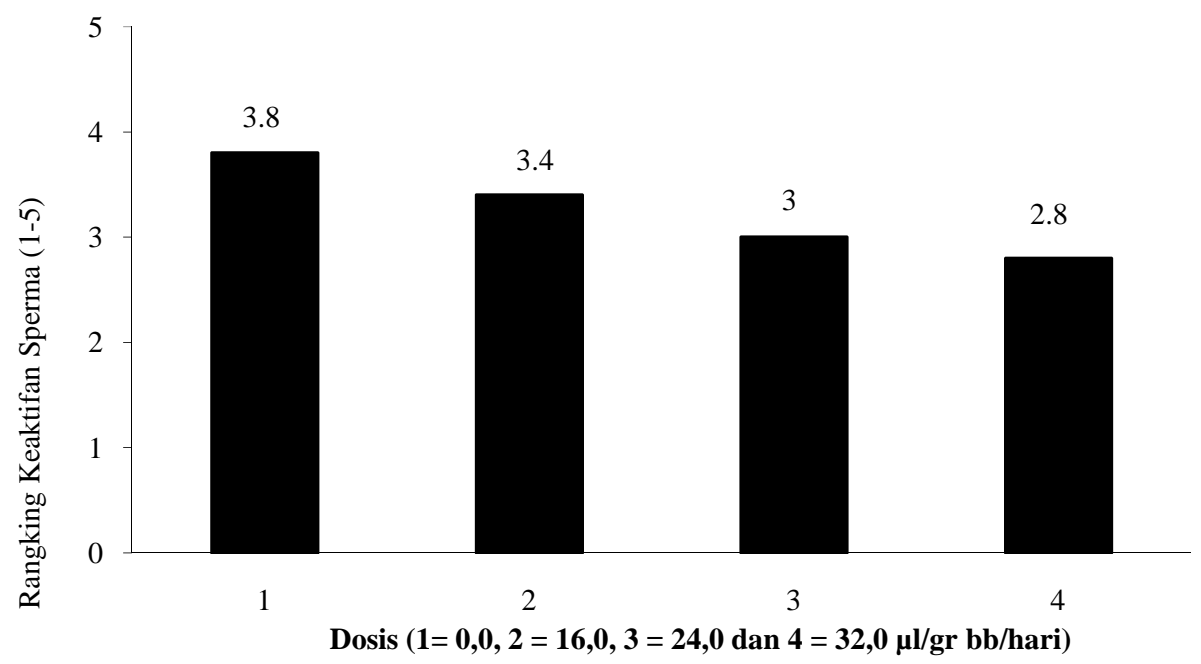

Gambar 4 Pengaruh Rebusan Air Akar Aru (Caesalpinea bonduc) Terhadap Rangking Keaktifan Sperma Mencit (Mus musculus) 


\section{Jumlah produksi sperma}

Pemberian air rebusan akar aru Caesalpinea bonduc pada mencit tidak menunjukan pengaruh secara signifikan terhadap jumlah sperma pada epididimis, ditunjukan dengan hasil uji statistik dimana $\mathrm{F}$ hit< F tab $(2,45: 3,24)$. Namun demikian tampak kecenderungan menurun dari jumlah sperma epididimis dengan meningkatnya dosis yang diberikan, pada dosis $0,0 \quad 1$ setinggi 8,12 juta sedangkan pada dosis 32,0 1 setinggi 3,34 juta (gambar 5).

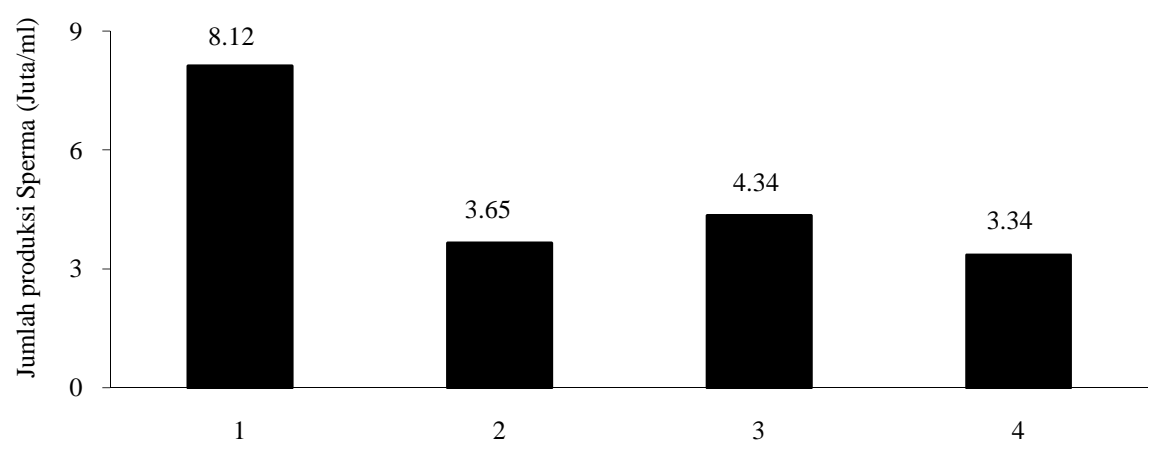

Dosis $(1=0,0,2=16,0,3=24,0$ dan $4=32,0 \quad$ 1/gr bb/hari $)$

Gambar 5 Pengaruh Rebusan Air Akar Aru (Caesalpinea bonduc) Terhadap Jumlah Produksi Sperma Mencit (Mus musculus)

Pemberian air rebusan akar aru Caesalpinea bonduc pada mencit menunjukan pengaruh secara signifikan terhadap peningkatan jumlah (\%) sperma abnormal dan hasil uji antar kelompok menunjukan bahwa terdapat perbedaan signifikan dalam persen sperma abnormal antara kelompok dosis 0,0 l dengan 24,0 dan $32,0 \quad 1 / g r \quad$ bb/hari. Terjadinya peningkatan persen ketidak normalan sperma dapat disebabkan pada proses spermatogenesis yang terjadi pada seminiferus tubul tidak normal, akibat unfavorable biochemical microenvironment within testicular tissue (Pantke, et al. 2008) dan ketidak normalan $14 \%$ and $50 \%$ menyebabkan infertil pada laki-laki (Cooper, dan Yeung, 2006). Hal lain bisa akibat penghambatan hormon pada testis seperti androgens many other hormonal factors have been postulated to play a role in regulating epididymal function (Robaire, et al., 2006), sehingga sperma yang mengalir pada epididimis dalam keadaan tidak normal.

Selain itu bisa disebabkan pada proses pematangan dari seminiferus tubule ke epididimis bagian ekor tidak mendapat suplai senyawa kimia yang normal yang disebabkan sekresi sel-sel sepanjang epididimis tidak normal mengakibatkan pematangan sperma tidak normal, seperti rendahnya kadungan cairan epididimis yang biasa ditemukan terdapat 12 macam protein unik: 6 protein hanya ditemukan caput dengan BM 30.000, $31.000,323.000,17.400,18.700$ dan 21.400 $\mathrm{kda}, 3$ jenis protein hanya terdapat pada korpus : 12.800, 39.800 dan 90.600 kda dan 3 protein jenis lain hanya terdapat di cauda; 10.900. 56.300 dan 63.000 (Jones, 1997). Juga emapat konsentrasi protein 20, 40, 200, $400 \mathrm{mg} / \mathrm{ml}$ seemed to have the best effect on sperm (Ding, et al., 2007) dan presence of $35,25,18 \mathrm{kDa}$ proteins both in the epididymal fluid and cauda sperm indicate 
that these proteins are associated with goat buck sperm maturation and fertility (Cheema, et al. 2011). Ketidak normalan tersebut bisa disebabkan masalah hormonal atau sekresi senyawa dan proses kimiawi pada epididimis sehingga arah untuk kontrasepsi pada laki-laki bagaimana mempengaruhi sperma ketika proses pembentukan dan pematangan agar sperma tidak mampu membuahi sel telur

Proses penyerapan ion pada saluran epididimis tersebut berbeda, pada bagian kaput penyerapan $\mathrm{Na}$ cenderung menurun, $\mathrm{K}$ dan $\mathrm{Na}$ naik, pada bagian corpus penyerapan $\mathrm{K}$ dan $\mathrm{P}$ meningkat, namun pada bagian kauda penyerapan $\mathrm{Na}, \mathrm{Cl}, \mathrm{Mg}$ dan $\mathrm{P}$ menurun (Jones dan Clulows, 1987). Hal ini ada hubungan dengan hasil pengamatan jumlah spermatogonia dan spermatosit yang menurun pada dosis tinggi 24, 0 dan 32,0

$1 / \mathrm{gr}$ bb/hari. Penurunan tersebut tidak hanya dari segi jumlah tapi dari segi kualitas sehingga pada proses tahap selanjutnya akan tampak tidak normal. Selama dalam epididimis sperma mengalami pematangan dengan perubahan secara kimia dan fisik seperti perubahan struktur (Olson dan Orgebine-Crist, 1982) penambahan dan pengurangan protein (Brook dan Tiver, 1983), muatan permukaan (Velazquez dan Rosado, 1982), peningkatan ikatan disulfida (Huang et al, 1984; Calvin dan Bedford, 1974), permiabilitas membran (Glover, 1982), penurunan kandungan kolesterol (Gwatkin, 1977), peningkatan keaktifan dan kemampuan membuahi sel telur (Yanagimachi, 1994), perubahan orientasi kepala dan perkembangan akrosom (Setiadi, et al., 1997a), peningkatan motilitas (Lin, et al, 2000), peningkatan membran fluiditas (Rathi, et al, 2000) serta numerous secreted epididymal proteins bind to the sperm during passage (Ding, et al., 2007), include changes in its lipid and protein composition, modifications of surface proteins, and increased total negative charge of the extracellular surface (Kawano, 2011), the capacity for motility has been acquired-it is enforced by low $\mathrm{pH}$, low concentrations of sodium (Na1) and high concentrations of potassium (K1) atau the presence of viscous mucoproteins (Cooper, 2011), dan pendorong utama pergerakan air sepanjang saluran eferan dan kauda epdidimis adalah $\mathrm{Na}+\mathrm{K}+-$ ATPase yang terdapat pada membran basolateral (Robaire, et al. 2006), serta senyawa ERp29 pada membaran mencit berubah selama transit dalam epdidimis dan protein merupakan satu faktor penting yang berperan dalam pembuahan (Ying, et al. 2010).

Pemberian air rebusan akar aru Caesalpinea bonduc pada mencit menunjukan pengaruh secara signifikan terhadap penurunan jumlah (\%) sperma hidup dan hasil uji antar kelompok menunjukan bahwa terdapat perbedaan antara kelompok dosis 0,0 1 dengan 16,0, 24,0 dan 32,0 1/gr bb/hari. Penurunan persen jumlah sperma hidup pada epididimis kemungkinan disebabkan terjadi perubahan sekresi cairan dan mineral oleh sel-sel epitel epididimis yang menyebabkan ketidaknormalan kandungan cairan epididimis yang diperlukan oleh sperma untuk melakukan perubahan baik secara fisk maupun kimia, sehingga sperma tersebut mampu membuahi sel telur. Tetapi karena terjadi kelainan kandungan sehingga bisa menyebabkan peningkatan jumlah sperma yang mati. Proses tersebut terjadi bisa disebabkan senyawa yang terdapat pada rebusan akar aru menekan atau menghambat proses sekresi sel epitel disebabkan terhambatnya hormon atau senyawa kimia tertentu yang biasa menstimulasi sel untuk melakukan sekresi atau sintesa senyawa tertentu dalam sel untuk disekresikan ke dalam saluran epididimis.

Pemberian air rebusan akar aru Caesalpinea bonduc pada mencit menunjukan pengaruh secara signifikan penurunan terhadap jumlah (\%) sperma motil dan hasil uji antar kelompok menunjukan bahwa terdapat perbedaan antara kelompok dosis $0,0 \quad 1$ dengan 24,0 dan $32,0 \quad 1$. Penurunan persen sperma motil bisa 
disebabkan karena secara fisik tidak normal atau disebabkan karena proses pematangan selama dalam epididimis tidak normal dari segi waktu dan sekresi senyawa atau ion dari sel epitel permukaan epididimis tidak normal sehingga motilitasnya semakin menurun. Selama proses pematangan sperma mengalami perubahan-perubahan secara fisik dan kimia dimana terjadi perubahanperubahan sesuai dengan kondisi di sepanjang saluran, karena kandungan senyawa pada setiap bagian epididimis (caput, corpus dan cauda) berbeda, sehingga terjadi penambahan dan pengurangan senyawa yang akhirnya sperma lebih siap membuahi dan lebih motil yang merupakan satu persyaratan utama untuk dapat bertemu atau menemukan sel telur pada bagian saluran reproduksi betina.

Penurunan motilitas dari sperma bisa disebabkan sekresi senyawa yang dilakukan sel epitel epididimis tidak normal, seperti rendahnya senyawa GPX has function in protecting mammalian spermatozoa from loss of motility (Chabory, et al. 2010), antioxidants, such as superoxide dismutase, catalase (low levels), vitamins $C$ and $E$ and small sulfhydryl-containing molecules (glutathione), protect spermatozoa from oxidative stress and related loss of motility (Gagnon dan Lamirande, 2006), sehingga proses pematangan tidak normal yang akan menghasilkan sperma kurang motil dan akhirnya akan menurunkan peluang terjadinya fertilisasi. Ketidak normalam sekresi bisa disebabkan pengaruh dari senyawa yang terdapat pada rebusan akar aru yang menekan atau mempengaruhi sel tersebut menjadi tidak berfungsi normal dalam mensekresikan senyawa atau ion zincalpha-2- glycoprotein (ZAG) as a complex, it is able to bind to the sperm membrane and initiate forward motility in immature, immotile bovine caput spermatozoa (Ding, et al., 2007) yang diperlukan sperma dalam proses pematangan dan terdapat korelasi positif antara aktivitas protein-carboxyl methylase pada sperma manusia dan persentase motil sperma (Gagnon, dan Lamirande, 2006).

Pemberian air rebusan akar aru Caesalpinea bonduc pada mencit menunjukan pengaruh secara signifikan terhadap penurunan rangking keaktifan sperma dan hasil uji antar kelompok menunjukan bahwa terdapat perbedaan dalam keaktifan sperma antara kelompok dosis $0,0 \quad 1$ dengan 24,0 dan $32,0 \quad 1$. Rangking keaktifan sangat dipengaruhi atau ditentukan oleh jumlah sperma hidup, ketidak-normalam dan motilitas dari persen jumlah sperma. Dari hasil penelitian ini jumlah sperma tidak normal semakin meningkat, jumlah sperma hidup semakain menurun dan mitilitas juga semakin menurun, keadan tersebut akan menyebabkan menurunnya rangking keaktifan sperma. Sehingga rangking keaktifan ini sangat tergantung dari proses spermatogenesis yang menghasilkan spermatid normal dan hidup berapa persen, kemudian setelah mengalami pematangan selama perjalanan dalam epididimis berapa persen yang dapat bergerak dengan normal, sehingga kalau proses tersebut berjalan normal maka rangking keaktifan akan tinggi dan akan menentukan tingkat keberhasilan sperma menemukan sel telur dalam waktu lebih awal sehingga lebih cepat membuhai sebelem masa hidup sperma dalam saluran reproduksi betina berakhir disebabkan keterbatasan lingkungan dan suplai makanan.

Pemberian air rebusan akar aru Caesalpinea bonduc pada mencit tidak menunjukan pengaruh secara signifikan terhadap jumlah produksi sperma pada epididimis. Hal ini mungkin disebabkan karena pemberian dosis hanya selama sepuluh hari sehingga hasil produksi sperma dari spermatogenesis sudah terjadi, sehingga tidak akan mengalami perubahan atau disebabkan kematian sperma selama perjalanan pada epididimis. tetapi kalau pemberian lebih lama spermatosit yang dihasil selama pemberian perlakuan akan sampai pada tahap pematangan atau sampai 
pada bagian ekor dari epididimis, sehingga akan tampak penurunan jumlah sperma yang disebabkan oleh perlakuan yang diberikan selama penelitian.

Air rebusan akar aru berpengaruh nyata terhadap kualitas sperma epididimis dari segi keabnormalan meningkat, motilitas menurun, jumlah sperma hidup menurun dan rangking keaktifan menurun, tetapi tidak berpengaruh signifikan pada jumlah produksi sperma, walaupun sudah tampak kecenderungan penurunan produksi sperma dengan meningkatnya dosis yang diberikan. Pengaruh tersebut bisa terjadi ketika pembentukan sperma atau ketika tahap proses pematangan pada epididimis terkait dengan senyawa yang disekresikannya dan proses kimiawinya.

\section{Kesimpulan}

Pemberian air rebusan akar aru Caesalpinea bonduc pada mencit memberikan pengaruh secara signifikan terhadap jumlah (\%) sperma abnormal, dan terdapat perbedaan \% sperma abnormal antara kelompok dosis 0,0 l dengan 24,0 dan 32,0 1 serta antara 16,0 1 dengan 24,0 dan 32,0 1/gr bb/hari; Jumlah (\%) sperma hidup dan terdapat perbedaan antara kelompok dosis 0,01 dengan $16,0,24,0$ dan 32,0 1/gr bb/hari; Jumlah (\%) sperma motil dan terdapat perbedaan antara kelompok dosis 0,0 1 dengan 24,0 dan 32,0

1/gr bb/hari; dan rangking keaktifan sperma terdapat perbedaan antara kelompok dosis 0,01 dengan 24,0 dan $32,0 \mathrm{l} / \mathrm{gr}$ bb/hari.

\section{DAFTAR PUSTAKA}

Adil, E. I. M. (1997). Pengaruh antifertilitas buag tekokak Solanum torvum terhadap laju implantsi mencit Mus musculus, Majalah Hasil Penelitian UI 30:8-15.

Brook, D. E dan Tiver, K (1983). Localization of epididymal secretory protein on rat spermatozoa J. Reprod. Fert. 69:651-657.
Calvin, H.I dan Bedford, J. M (1984). Formation of disulfide bond in the nucleus acessory structure of mammalian spermatozoa during maturation in the epididymis $J$. Reprod Fert. 13:65-75

Chabory, E. et al. (2010). Mammalian glutathione peroxidases control acquisition and maintenance of spermatozoa integrity. J. Anim. Sci. 88:1321-1331. www.journalofanimalscience.org. Akses 20 Agustus 2013.

Cheema, R.S. et al. (2011). Correlation between the proteins and protein profile(s) of different regions of epididymis and their contents in goat buck. Animal Science Papers and Reports vol. 29 1, 75-84.

Cooper, T.G. (2011). The epididymis, cytoplasmic droplets and male fertility. Asian Journal of Andrology (2011) 13, 130-138. http://www.asiaandro.com/temp/review2.pdf. Akses 25 September 2013

Cooper, T.G. dan Yeung, C-H (2006). Sperm maturation in the human epididymis, dalam The Sperm Cell Production, Maturation, Fertilization, Regeneration. Christopher J. De Jonge dan Christopher L. R. Barratt (edts). Cambridge: Cambridge University Press

Dalimartha, S. (2002). Khasiatnya telah diuji khusus, Trubus XXXIII Januari 2002, p-49.

Ding, Z., et al. (2007).Identification of Sperm Forward Motility-Related

Proteins in Human Seminal Plasma. Molecular Reproduction and Development 74:1124-1131.

Gagnon, C. dan Lamirande, E. (2006). Controls of sperm motility dalam The Sperm Cell Production, Maturation, Fertilization, Regeneration. Christopher J. De Jonge dan Christopher L. R. Barratt (edts). Cambridge: Cambridge University Press.

Glasier, A. (2000) Future direction for contracepstion, Serial abstract J Reprod. Fert 25:7.

Glover, T.D (1982) reaction of rabbit spermatozoa to nigrosin eosin following ligation of the epididymis. Int. J. Fert. 7:1-10.

Gwatkin, R. B. L. (1977) Fertilisation mechanism in man and mammals, Plenum Press, NY. 
Haryadi, B. dan Wijanyanti, G. E. (1996). Uji fertilitas mencit yang diberi antifertikitas buah ranti, Makalah Seminar Nasional Biologi Reproduksi, Purwekerto.

Huang, T. T. F, Kosower, N. S dan Yanagimachi, R. (1984) Localization of thiol and disulfide groups in guines pig spermatozoa during maturation and capasitation using bimane fluorescent labels Biol Reprod. 31:787-809.

Kawano, N. (2011). Lipid Rafts: Keys to SpermMaturation, Fertilization, and Early Embryogenesis. Journal of Lipids. Volume 8, $1-11$. http://www.ias.ac.in/jarch/jbiosci/7/191195.pdf, Akses 29 Juli 2013.

Jones, R. C. (1997). Changes in protein composition of the luminal fluid a long the epididymis of tammar wallaby J. Reprod. Fert. 80-193-199.

John, R. C dan Clulow, J. (1987) .Regulation of the elements composition of epididymal fluid in tammar wallaby J. Reprod. Fert. 81:583-590.

Lin, M., Zhang, X, Mudoch, R., and Airke, R. J. (2000). In vitro culture of brush tai possum epididymal epithelium and induce of epididymal sperm amturation in co culture. $J$. Reprod Fert. 119:1-14.

Olson, GE and Orgebin-Crist, MC (1982) Sperm changes during epididymis maturation. Ann N Y. Acad Sci 383:372-391.

Pantke, P., et al. (2008). Testicular Sperm Retrieval in Azoospermic Men. European Urology Supplements 7 . 703-714, Journal homepage: www.europeanurology.com. Akses 20 Januari 2013

Rathi, R., Colenbrander, B., Bevers, M. M., Gadella, B.M (2000). Evaluation of invitro capacitation of stallion spermatozoa. Seri abstract J. Reprod. Fert 26:27.

Riono, Y. V., Blache, D., Martin, G. B. (1998). Ingestion of extract of mangosteen leaves decrease daily sperm production and epididymis sperm reserves in rats, Reproductive Biologi, 39.
Robaire, B. et al. (2006) .The Epididymis. Dalam Knobil and Neill's Physiology of Reproduction,Third Editione, Jimmy D. Neill (edt), New York : Elsevier.

Rodger, J. C., Cosin,S. J., Mate, K. (1991). A simple glycerol based freezing protocol for the semen of marsupial, a common brushtail possum Reprod. Fertl. Dev. 3:119-125.

Setiadi, D., Lin, M. dan Rodger. J.C. (1997). Post testiculer development of Macropus eugenii spermatosoa, J. Anatomy :190:275-288.

Setiadi, D., Bahri, S., Sukib, Santoso, D. (1997). Pengaruh ekstrak buah ranti terhadap spermatosit mencit. Laporan Penelitian.

Setiadi, D. dan Mertha, I. W. (2000) . Pengaruh obat tradisional air rebusan akar aru terhadap organ reproduksi, hati dan ginjal. Laporan Penelitian.

Soeksimanto, A., Simanjuntak, P. (2003). Pengaruh fraksi aktif tumbuhan Aglania angustifolia terhadap sel-sel reproduksi mencit (Mus musculus), J.Bio SMART Vol 5 N0 1:52-55

Sujana (1992). Metode statistik, edisi 5. Tarsito Bandung.

Syarieta, E. (2002). Kadar gula darah dengan 3 serangkai, Trubus XXXIII April 2002, p-57.60 .

Velazquez, A. dan Rosado (1982). Cell polarography I, study of the surface ghracteristic of human spermatozoa Fertil. Steril 23:565-570.

Ying, X , et al. (2010). Endoplasmic reticulum protein 29 (ERp29), a protein related to sperm maturation is involved in sperm-oocyte fusion in mouse. Reproductive Biology and Endocrinology , $\quad 8: 10$ http://www.rbej.com/content/8/1/10

Yanagimachi, R. (1994). Mammalian fertilisation :In the physiology of reproduction, Knobil, E. Jimmy N. (eds) Ra ven Press NY.pp 135185. 